\title{
Structural and compositional dynamics of strictly protected woodland communities with silvicultural implications, using Białowieża Forest
}

\section{as an example}

\author{
Bogdan Brzeziecki ${ }^{1}$ (D) Kamil Bielak ${ }^{1}$ - Leszek Bolibok ${ }^{1}$ Stanisław Drozdowski ${ }^{1}$ Jacek Zajączkowski ${ }^{1}$. \\ Henryk Żybura ${ }^{1}$
}

Received: 8 December 2017 / Accepted: 22 August 2018 / Published online: 14 September 2018

(C) The Author(s) 2018

\begin{abstract}
- Key message Long-term strict protection of woodland communities may lead to their compositional simplification and homogenisation.

- Context In the past, it has often been postulated that structures and processes typical for natural forests should be mimicked by silvicultural activities in the case of managed tree stands.

- Aims To determine which features and traits of natural woodland communities (alongside typical old-growth attributes) should be imitated in managed forests, as well as which should not (and for what reasons).

- Methods Tree data from five permanent study plots (of a total area of 15.44 ha) established in 1936 in the core area of the Białowieża National Park (NE Poland) are used to calculate several quantitative indices describing the temporal dynamics (in terms of stand structure and composition) of eight major woodland community types.

- Results Most structural attributes revealed rather high stability over time. In contrast to these, during the observation period, noticeable changes in the composition of particular Białowieża woodland communities have been taking place, related to declining occurrence and reduced roles characteristic for a large number of tree species.

- Conclusion In many ways, natural forests can serve as an important model for managed forest stands. However, in certain circumstances, silvicultural treatments counteracting natural developmental trends may appear to be indispensable, especially when more diverse and stable tree species composition (at a given spatial and temporal scale) is indicated or desirable.
\end{abstract}

Keywords Close-to-nature silviculture $\cdot$ Community dynamics $\cdot$ Natural forest $\cdot$ Stand composition $\cdot$ Stand structure $\cdot$ Structural index

Handling Editor: Laurent Bergès

Contribution of the co-authors Bogdan Brzeziecki: data gathering, supervising the work and writing the paper.

Kamil Bielak: data gathering, running the statistical data analysis and preparation of figures.

Leszek Bolibok: data gathering, preparation of figures and support in reviewing the paper.

Stanisław Drozdowski: data gathering and support in reviewing the paper. Jacek Zajączkowski: data gathering, running the data analysis and support in reviewing the paper.

Henryk Żybura: management of the database.

Electronic supplementary material The online version of this article (https://doi.org/10.1007/s13595-018-0767-x) contains supplementary material, which is available to authorized users.

Bogdan Brzeziecki

bogdan_brzeziecki@sggw.pl

1 Department of Silviculture, Warsaw University of Life Sciences, Nowoursynowska 159/34, 02-776 Warsaw, Poland

\section{Introduction}

Scientific interest in well-preserved (virgin, pristine, primeval, prime, natural, old-growth, unmanaged, untouched, strictly protected) forests has a very long history, dating back to the second half of the nineteenth century, if not longer (Lähde et al. 1999; Pommerening and Murphy 2004; Brang 2005). For a long time, the remnants of such forests served as important observation and research objects, above all for foresters interested in developing and promoting a kind of close-tonature silviculture (Leibundgut 1959, 1982; Lähde et al. 1999; Schütz 1999a; Brang 2005; O’Hara 2014, 2016; Schütz et al. 2016). This concern was based on the underlying assumption that a thorough knowledge of natural structures and processes might be of great help in developing effective silvicultural strategies aimed at creating sustainable, productive, economically beneficial and ecologically sound forests. 
Recent changes in social preferences, expectations and requirements vis-à-vis forests, and particularly the pronounced interest in and concern for biodiversity conservation, have led to renewed interest in close-to-nature forestry. The latter's core philosophical and even practical element is that managed forest stands should emulate the attributes, structures, processes and dynamics that characterise comparable natural forest (Zukrigl 1991; Peterken 1999; Çolak et al. 2003; Gamborg and Larsen 2003; Franklin et al. 2002; Spiecker 2003; Pommerening and Murphy 2004; Parviainen 2005).

However, certain authors have recently been raising doubts as to the usefulness of natural forests as points of reference for modern, sustainable forestry (Brang 2005; Meyer 2005; O’Hara 2016). For example, O’Hara (2016) argues that, "in an era of rapid environmental change, a simple emulation of natural systems and processes will not be enough to secure the capacity of forests to withstand and adapt to ongoing climate change, and to provide a wide array of forest-ecosystem benefits and services of importance to society".

Taking into account the current controversies concerning the relationships between natural and managed forests, in this paper, we present an analysis of the long-term structural and compositional dynamics characterising the natural woodland communities occurring in Białowieża Forest, NE Poland (subject to strict protection for around 100 years). The primary goal of our work was to determine which features of natural woodland communities in the Białowieża area could (or should) be imitated in managed forests, as well as which should not (and for what reasons). Above all, we try to assess whether the communities investigated are stable enough in terms of their structure and composition, to serve as a model which could be promoted in the conditions of managed forests.

In contrast to many earlier studies focused mainly on the dead component of natural, strictly protected stands, and on so-called old-growth attributes (Bauhus et al. 2009; Stokland et al. 2012; Burrascano et al. 2013; Paillet et al. 2015), our analysis is limited to live trees and involves several quantitative parameters (such as tree density, stand basal area, indices of species diversity and size variation) describing the structure and composition of the living part of natural forest stands.

\section{Material and methods}

\subsection{Study area}

Białowieża/Belovezhskaya Forest covers $1450 \mathrm{~km}^{2}$ in total, of which $600 \mathrm{~km}^{2}$ is on the Polish side of the state border with Belarus and the remaining $850 \mathrm{~km}^{2}$ on the Belarusian side.

Białowieża Forest is situated on a flat, undulating plain at between 135 and $190 \mathrm{~m}$ a.s.l., built from glaciofluvial sands, gravels and clays (Kwiatkowski 1994). The climate has features of both a continental and an Atlantic character. The average annual air temperature is $7.0^{\circ} \mathrm{C}$, with the coldest month being January $\left(-4.6^{\circ} \mathrm{C}\right)$ and the warmest being July $\left(18.2^{\circ} \mathrm{C}\right)$. The mean annual precipitation is of $631 \mathrm{~mm}$, while snow cover lasts for 92 days a year on average (Faliński 1986).

Within Białowieża Forest, it is possible to find a range of different woodland community types. There is coniferous forest (with dominant Pinus sylvestris L. and Picea abies (L.) Karst.), mixed coniferous/broadleaved forest (Pinus sylvestris L., Picea abies (L.) Karst. and Quercus robur L.), mixed broadleaved/coniferous forest (Quercus robur L., Tilia cordata Mill., Carpinus betulus L. and Picea abies (L.) Karst.), broadleaved forest (Quercus robur L., Tilia cordata Mill., Carpinus betulus L. and Acer platanoides L.), streamside alder-ash forest (Alnus glutinosa (L.) Gaertn. and Fraxinus excelsior L.) and black alder bog forest (Alnus glutinosa (L.) Gaertn., Betula pubescens Ehrh.). These forest types, based on phytosociological units, reflect the presence of an ecological gradient of soil fertility and water availability. Coniferous forest can be found on the most well-drained, nutrient-poor soils, while broadleaved and floodplain forests both occur on highly productive soils rich in organic matter, but differing in terms of water supply. For some periods of the year at least, floodplain forests are inundated. Mixed coniferous/broadleaved forests occupy an intermediate position on the soil fertility gradient. A detailed phytosociological description of these vegetation units has been provided by Faliński (1986), among others.

For a long time from the fourteenth through to the early twentieth centuries, Białowieża Forest enjoyed a status as an extensive hunting area that served to protect it from more widespread colonisation and from the commercial timber extraction that occurred in most European forests in similar climatic and topographic characteristics (Więcko 1984; Faliński 1986; Samojlik et al. 2013).

It is at the centre of the (Polish) Białowieża Forest that the Białowieża (Białowieski) National Park (NP) is located $\left(52^{\circ}\right.$ $\left.30^{\prime}-53^{\circ} 00^{\prime} \mathrm{N}, 23^{\circ} 50^{\prime}-24^{\circ} 15^{\prime} \mathrm{E}\right)$. The park was established in 1921 , initially over the $47.5 \mathrm{~km}^{2}$ which now form the socalled Strict Reserve. As pointed out on different occasions by several authors (Jones 1945; Faliński 1986, 1988; Peterken 1996; Parviainen 2005), the Strict Reserve of Białowieża NP contains that part of the Białowieża Forest which has never suffered seriously from human impact and can, nowadays, be regarded as the best preserved remnant of natural forests once covering most of the Central European lowlands.

\subsection{Data}

In 1936, work was carried out to establish five permanent research plots within Białowieża NP (specifically the section 
enjoying strict protection since 1921), with the aim being for the long-term dynamics of natural woodland communities to be studied (Włoczewski 1954; ESM Fig. 1). The plots are transects of varying widths $(40-60 \mathrm{~m})$ and lengths (200$1380 \mathrm{~m}$ ), running across the area's main topographical zones. The total sampled area amounts to $15.44 \mathrm{ha}$. The locations of the transects were selected to ensure coverage of the whole range of site conditions and main types of woodland communities encountered in Białowieża NP. Thus far, the transects have been sampled on a total of seven major occasions: in 1936, 1955-1959, 1968-1972, 1981-1983, 1991-1993, 2001-2003 and 2011-2013. In the present study, it is the average years of observations that are used, the same for all transects, i.e. 1936, 1957, 1970, 1982, 1992, 2002 and 2012. During the first survey, all trees with a diameter at breast height (DBH) of at least $5 \mathrm{~cm}$ were identified and their spatial locations mapped. During subsequent censuses, similar measurements were made. Additionally, recruits, i.e. trees which had increased in diameter by up to $5 \mathrm{~cm}$ in the period between consecutive censuses, were identified, as well as trees which had died since the time of the last record (losses). A list of the most important tree species occurring in study plots is provided in Table 1.

In the late 1950 s, wide-ranging phytosociological studies were performed on all of the above transects (Witkowska 1956; Zaręba 1972 + unpublished manuscripts). On the basis of dominant tree species, as well as differences in soil conditions and ground flora

Table 1 A list of tree species occurring on permanent study plots located in the Strict Reserve of Białowieża NP

\begin{tabular}{|c|c|c|c|c|c|}
\hline No. & Tree species & Scientific name & Abbr. & N1936 & N2012 \\
\hline 1 & Pine & Pinus sylvestris L. & Psyl & 438 & 191 \\
\hline 2 & Birch & Betula sp. ${ }^{1}$ & Bpen & 1066 & 123 \\
\hline 3 & Aspen & Populus tremula $\mathrm{L}$. & Ptre & 117 & 17 \\
\hline 4 & Spruce & Picea abies (L.) Karst. & Pabi & 6364 & 1163 \\
\hline 5 & Oak & Quercus robur $\mathrm{L}$. & Qrob & 538 & 211 \\
\hline 6 & Hornbeam & Carpinus betulus L. & Cbet & 1257 & 4808 \\
\hline 7 & Lime & Tilia cordata Mill. & Tcor & 268 & 2308 \\
\hline 8 & Maple & Acer platanoides $\mathrm{L}$. & Apla & 192 & 76 \\
\hline 9 & Elm & Ulmus sp. ${ }^{2}$ & Ugla & 47 & 67 \\
\hline 10 & Ash & Fraxinus excelsior $\mathrm{L}$. & Fexc & 366 & 141 \\
\hline 11 & Alder & Alnus glutinosa (L.) Gaertn. & Aglu & 452 & 300 \\
\hline
\end{tabular}

N1936 and N2012 = the total number of trees in 1936 and 2012, respectively. The sequence of species corresponds to their relative position along a major environmental gradient from most oligotrophic to most eutrophic sites

${ }^{1}$ Betula pendula Roth. and B. pubescens Ehrh. (predominantly B. pendula)

${ }^{2}$ Ulmus glabra Hudson, U. laevis Pallas and U. minor Mill. (predominantly $U$. glabra) vegetation, the woodland communities occurring on sample plots were identified, and their spatial extent on each study plot was mapped (Fig. 1). Particular community types are represented by a varying number of patches (from 1 to 10). Summary information about community types and their total areas is provided in Table 2. In the present paper, the names of the communities are adjusted in line with the current phytosociological interpretation (Matuszkiewicz 2002). These communities play the role of the basic investigative units in subsequent analyses.

\subsection{Structural parameters and indicators}

To characterise the long-term dynamics experienced by particular woodland community types occurring in Białowieża NP, we used an approach similar to that suggested by O'Hara et al. (2007), albeit with some modifications. In so doing, we considered four fundamental aspects of the structural dynamics of tree stands, i.e. (1) stocking (total for all living trees present at the time of measurement, in terms of tree density $\left(N\right.$, trees $\left.\mathrm{ha}^{-1}\right)$ and stand basal area (BA, $\left.\mathrm{m}^{2} \mathrm{ha}^{-1}\right)$ ); (2) increment and productivity trends (estimated by means of basal area increment (Incr., $\mathrm{m}^{2} \mathrm{ha}^{-1}$ year $^{-1}$ ) and by reference to outgrowth (Out., $\mathrm{m}^{2} \mathrm{ha}^{-1}$ year ${ }^{-1}$ ), defined as the basal area of trees absent in any remeasurement, i.e. lost from the stand); (3) tree species diversity (expressed by reference to Shannon diversity $(\operatorname{Sh}(N), \operatorname{Sh}(\mathrm{BA}))$, Shannon evenness $(\operatorname{Ev}(N), \operatorname{Ev}(\mathrm{BA}))$, as well as the Berger-Parker index for species dominance (B-P $(N)$, B-P(BA)), all calculated using both the number of trees per species $(N)$ and the BA per species); and (4) differentiation to the tree diameters (assessed by means of Shannon diversity (Sh(Size)) and Shannon evenness $(\mathrm{Ev}(\mathrm{Size}))$ indices, using numbers of trees in 10-cm-diameter classes).

The mathematical equations used to calculate the above indices, along with detailed descriptions of their interpretation and ecological meaning, are given in O'Hara et al. (2007). All the parameters listed above were expressed graphically as time-series relationships. Measures of stocking, species diversity and tree size structure were determined for seven measurement dates. Stand increment and outgrowth were based on changes between these measurement dates and were expressed in relation to the midpoints of the six measurement intervals generated.

\subsection{Statistical analysis}

To determine if the measures mentioned above, covering most fundamental aspects of the long-term structural dynamics of tree stands, were constant over time and to quantify the differences in structural parameters among particular community types during the entire observation period, we used a mixedeffects linear model (Faraway 2016) 


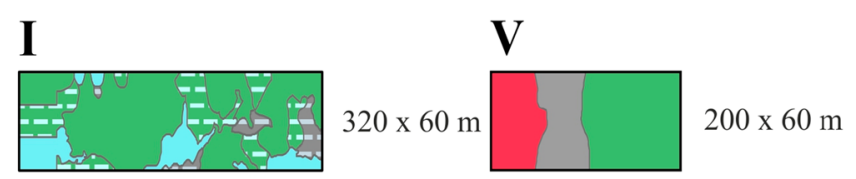

II

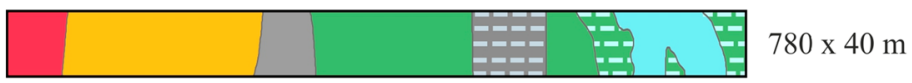

\section{III}

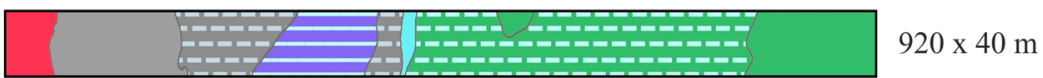

\section{IV}

\begin{tabular}{|c|c|c|c|c|c|c|c|c|c|}
\hline & & 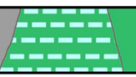 & 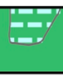 & is & 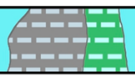 & ㄷ․ㄹ. & 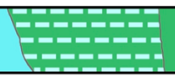 & 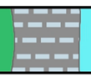 & $1380 \times 40 \mathrm{~m}$ \\
\hline 100 & 200 & & 500 & & & 100 & & & $1380 \mathrm{~m}$ \\
\hline
\end{tabular}

Legend

Vaccinio uliginosi-Pinetum

Peucedano-Pinetum

Serratulo-Pinetum, mossy variant

Serratulo-Pinetum, typical variant
므물 Querco-Piceetum

Tilio-Carpinetum typicum

Tilio-Carpinetum stachyetosum

Circaeo-Alnetum

Fig. 1 Spatial distribution and extent of woodland communities occurring on permanent study plots located in the Strict Reserve of Białowieża National Park

$$
\begin{aligned}
Y_{i j k}= & a_{0}+b_{0 k}+\left(a_{1}+b_{1 k}\right) \cdot \text { Year }_{i j k}+a_{2 j} \cdot C T_{j} \\
& +a_{3 j} \cdot \text { Year }_{i j k} \cdot C T_{j}+\varepsilon_{i j k}
\end{aligned}
$$

Table 2 A list of woodland communities occurring on permanent study plots in the Strict Reserve of Białowieża NP and their total area

\begin{tabular}{lllc}
\hline No. & Community & Abbr. & Area (ha) \\
\hline 1 & Vaccinio uliginosi-Pinetum & Vu-P & 0.42 \\
2 & Peucedano-Pinetum & Pe-P & 0.82 \\
3 & Serratulo-Pinetum, mossy variant & S-Pm & 1.70 \\
4 & Serratulo-Pinetum, typical variant & S-Pt & 1.46 \\
5 & Querco-Piceetum & Qu-P & 1.69 \\
6 & Tilio-Carpinetum typicum & T-Ct & 3.80 \\
7 & Tilio-Carpinetum stachyetosum & T-Cs & 3.89 \\
8 & Circaeo-Alnetum & Ci-A & 1.66 \\
& Total & & 15.44 \\
\hline
\end{tabular}

Community names after Matuszkiewicz (2002)
In Eq. (1), $Y$ represents the structural parameter of interest $(N, \mathrm{BA}, \mathrm{Sh}(N)$, etc.) for the time of survey $i$ and the given community type $j$ within the transect $k$. Year of observation and community type $C T$ are the explanatory variables. The latter is a dummy variable with eight levels corresponding to community types. Given that Year of observation proved statistically significant $(p<0.05)$, we also tested the effect of interaction of both fixed effects. The coefficients of fixed effects are $a_{0}$ to $a_{3}$, while $b_{0}$ and $b_{1}$ are random effects associated with transect identity $k$ and the intercept and slope of the fitted models, respectively $\left(b_{0 k} \sim N\left(0, \tau_{1}{ }^{2}\right), b_{1 k} \sim N\left(0, \tau_{2}^{2}\right)\right)$. With these random effects, we sought a possible transect-specific correlation among the observations. The symbol $\varepsilon_{i j k}$ stands for independent and normally distributed residuals, $\varepsilon_{i j k} \sim N\left(0, \delta^{2}\right)$. After the procedure of model fitting, standardised residual and normal quantile plots were assessed visually to ensure that the residuals were distributed approximately normally, centred at zero and characterised by constant variance. The slope coefficients and their significance were used as an indication of either upward or downward trends for the 
analysed variable over time. Finally, based on fitted models, all community types were contrasted among others, and on this basis, homogeneous groups were defined. To this end, the lsmeans $\mathrm{R}$ package (functions lsmeans and cld) by Lenth (2016) was applied. All statistical analyses were carried out using $\mathrm{R}$ (version 3.4.4; $\mathrm{R}$ Core Team 2018), by means of the nlme package for fitting models (Pinheiro et al. 2013).

\subsection{Dynamics of tree species composition}

To assess the degree of compositional dynamics, for each community type, we calculated the overall similarity of tree species composition (in terms of both tree density and basal area), between 1936 and 2012. For this purpose, we adapted a simple similarity coefficient, by means of which the percentage shares of trees can be compared (Badeck et al. 2001)

$S=1-\frac{\sum_{i=1}^{n}\left|f_{1936, i}-f_{2012, i}\right|}{200}$.

In the above equation, $f_{1936, i}$ and $f_{2012, i}$ are the percentage figures for species abundance in 1936 and 2012, respectively, and $n$ is the total number of species in the community of the given type. $S$ ranges from 0 (full dissimilarity, which means a total change in tree species composition) to 1 (full similarity, i.e. stable tree species composition over the considered study period).

To assess the changing roles of tree species in the composition of the woodland communities of Białowieża NP, we calculated importance values for particular species, defined as an arithmetic average derived from both relative density and relative basal area, at the initial time of measurement (in 1936) and most recently (in 2012).

\subsection{Graphical visualisation of the long-term changes in stand structure and composition}

To present general forest structure and composition, and changes in these over time, in an eye-catching and readily studied form, we have produced a series of virtual stand vertical profiles embracing $50 \mathrm{~m} \times 10 \mathrm{~m}$ plots. To do this, we first determined diameter distributions by tree species, for particular vegetation types. In the second step, we recalculated stem numbers in particular diameter classes for an area of $500 \mathrm{~m}^{2}$ (corresponding to the size of a virtual transect). Finally, numbers of trees in particular size classes (rounded to 1 when necessary) were imported into the BWINPro program (Nagel and Schmidt 2006), where they were used to construct stand profiles representing average conditions (in terms of tree species composition and diameter structure) in a given community type and in respect of two points in time, i.e. 1936 and 2012. In these profiles, tree heights and basic crown parameters were determined using allometric relationships established for Białowieża tree species (Bolibok and Brzeziecki 2000).

\section{Results}

\subsection{Stocking (growing space occupancy)}

After an initial increase during the first measurement interval, both mean density $\left(N\right.$, trees $\left.\mathrm{ha}^{-1}\right)$ and mean BA $\left(\mathrm{m}^{2} \mathrm{ha}^{-1}\right)$ decreased over time (Table 3). Density declined more markedly than basal area (with a $15 \%$ reduction in the former
Table 3 Mean values for structural parameters used to characterise the long-term stability of woodland communities occurring in Białowieża NP

\begin{tabular}{|c|c|c|c|c|c|c|c|c|}
\hline Structural parameter & 1936 & 1957 & 1970 & 1982 & 1992 & 2002 & 2012 & Mean \\
\hline$N\left(\right.$ trees $\left.\mathrm{ha}^{-1}\right)$ & 719 & 791 & 773 & 676 & 639 & 647 & 609 & 693 \\
\hline $\mathrm{BA}\left(\mathrm{m}^{2} \mathrm{ha}^{-1}\right)$ & 34.1 & 36.5 & 36.3 & 35.1 & 34.1 & 34.5 & 32.2 & 34.7 \\
\hline $\operatorname{Sh}(N)$ & 1.13 & 1.25 & 1.31 & 1.32 & 1.31 & 1.27 & 1.15 & 1.25 \\
\hline $\mathrm{Sh}(\mathrm{BA})$ & 1.35 & 1.38 & 1.39 & 1.41 & 1.45 & 1.47 & 1.45 & 1.41 \\
\hline $\operatorname{Ev}(N)$ & 0.63 & 0.65 & 0.68 & 0.69 & 0.69 & 0.68 & 0.62 & 0.66 \\
\hline $\mathrm{Ev}(\mathrm{BA})$ & 0.75 & 0.72 & 0.72 & 0.73 & 0.76 & 0.78 & 0.78 & 0.75 \\
\hline $\mathrm{B}-\mathrm{P}(N)$ & 0.58 & 0.54 & 0.50 & 0.47 & 0.47 & 0.48 & 0.55 & 0.51 \\
\hline $\mathrm{B}-\mathrm{P}(\mathrm{BA})$ & 0.45 & 0.44 & 0.43 & 0.43 & 0.40 & 0.40 & 0.42 & 0.42 \\
\hline Sh(Size) & 1.38 & 1.52 & 1.57 & 1.61 & 1.49 & 1.36 & 1.39 & 1.47 \\
\hline $\operatorname{Ev}(\operatorname{Size})$ & 0.66 & 0.73 & 0.72 & 0.77 & 0.68 & 0.62 & 0.63 & 0.69 \\
\hline Incr. $\left(\mathrm{m}^{2}\right.$ ha $^{-1}$ year $\left.^{-1}\right)$ & 0.46 & 0.45 & 0.48 & 0.51 & 0.48 & 0.55 & & 0.49 \\
\hline Out. $\left(\mathrm{m}^{2}\right.$ ha $^{-1}$ year $\left.^{-1}\right)$ & 0.41 & 0.50 & 0.62 & 0.65 & 0.48 & 0.82 & & 0.58 \\
\hline
\end{tabular}

For abbreviations of parameter names, see Section 2.3 
between 1936 and 2012, as opposed to a 6\% decline in basal area during that period). The long-term downward trend for density was confirmed by the results of the regression procedure. In this case, the slope of the regression line was negative and statistically significant (Fig. 2a; Table 4). For basal area likewise, the slope of the regression line was also a)

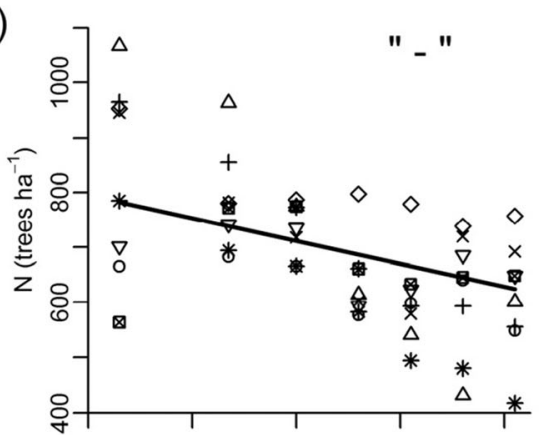

b)

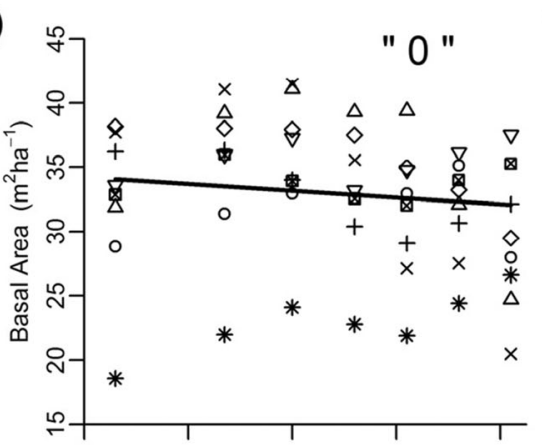

c)

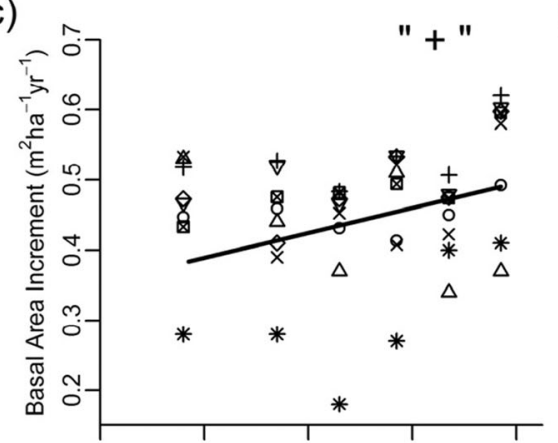

d)

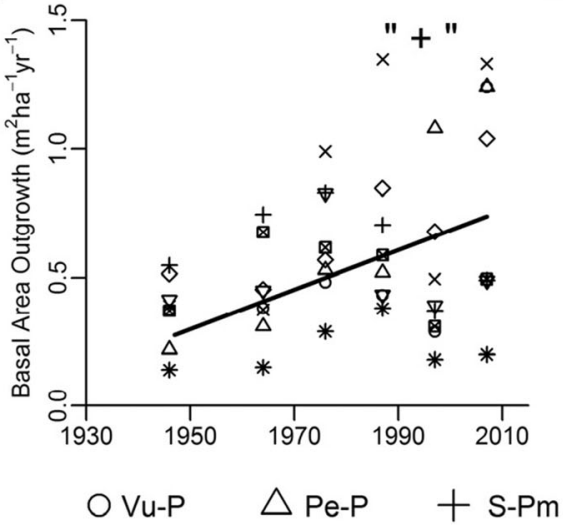

e)

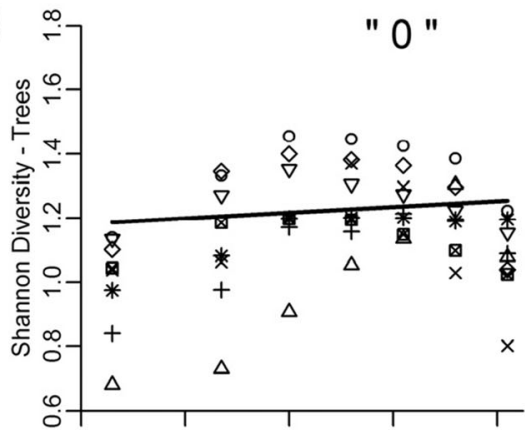

f)

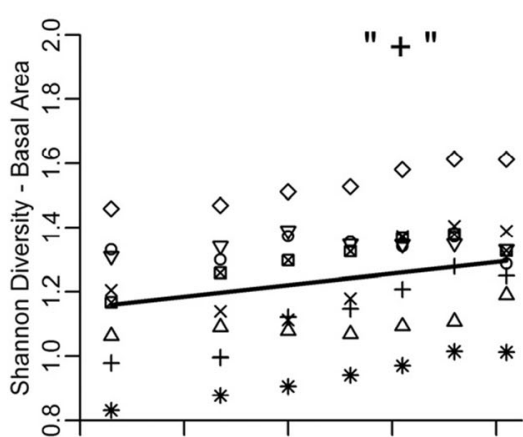

g)

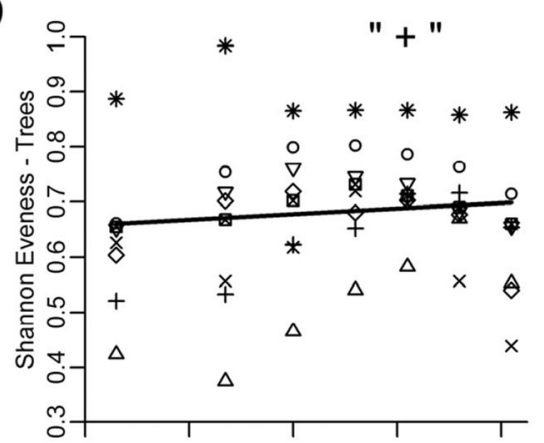

h)

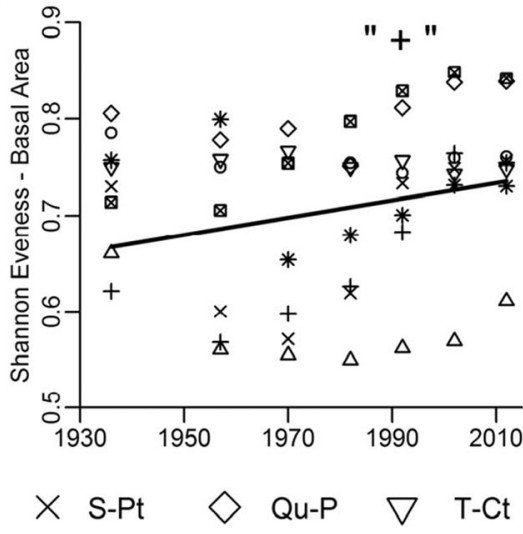

i)

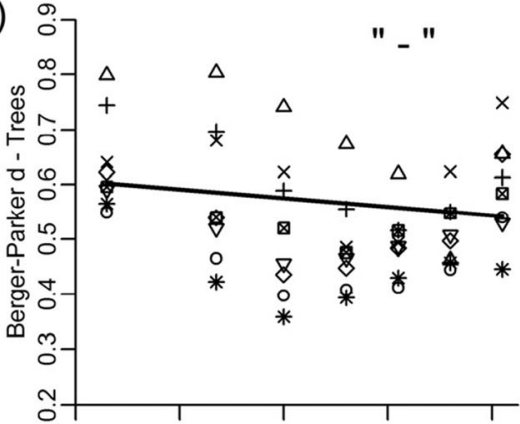

k)

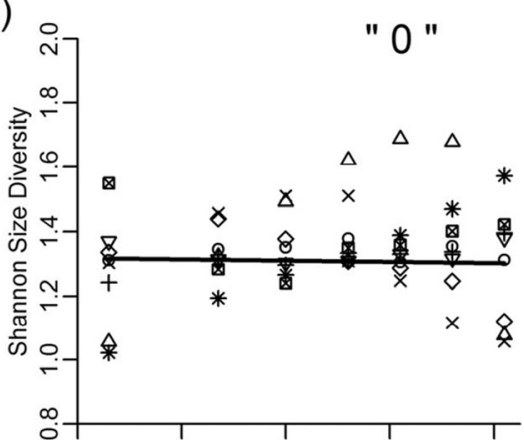

l)

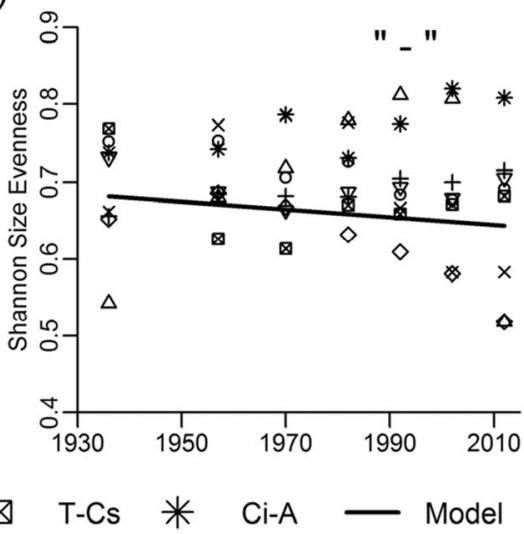

Fig. 2 Structural parameters for Białowieża's natural woodland communities. Solid lines represent general temporal trends as depicted by linear regression. "+", "-" and " 0 " mean that, in statistical terms, the general trend for a given structural index is positive, negative or non- existent, respectively. Different symbols denote mean values for a given index in the case of a particular community type. See Table 2 for abbreviations of community names 
Table 4 Results for a mixed-effects linear model (Eq. (1)), depicting general temporal trends and the differences in structural parameters among Białowieża's natural woodland communities

\begin{tabular}{|c|c|c|c|c|c|c|c|c|c|}
\hline Structural parameter & Year & $\mathrm{Vu}-\mathrm{P}$ & Pe-P & S-Pm & S-Pt & Qu-P & $\mathrm{T}-\mathrm{Ct}$ & $\mathrm{T}-\mathrm{Cs}$ & $\mathrm{Ci}-\mathrm{A}$ \\
\hline \multirow[t]{2}{*}{$N\left(\right.$ trees $\left.\mathrm{ha}^{-1}\right)$} & $-2.086^{* * *}$ & 617 & 624 & 699 & 778 & 747 & 697 & 715 & 664 \\
\hline & 0.4170 & 88 & 88 & 52 & 52 & 44 & 41 & 41 & 45 \\
\hline \multirow[t]{2}{*}{$\mathrm{Ba}\left(\mathrm{m}^{2} \mathrm{ha}^{-1}\right)$} & -0.0261 & $24.68^{\mathrm{a}}$ & $36.09^{\mathrm{ab}}$ & $32.30^{\mathrm{ab}}$ & $34.94^{\mathrm{ab}}$ & $32.77^{\mathrm{ab}}$ & $34.51^{\mathrm{ab}}$ & $35.74^{\mathrm{b}}$ & $31.86^{\mathrm{ab}}$ \\
\hline & 0.0178 & 3.65 & 3.65 & 2.07 & 2.07 & 1.71 & 1.57 & 1.56 & 1.71 \\
\hline \multirow[t]{2}{*}{$\operatorname{Sh}(N)$} & 0.0009 & $1.18^{\mathrm{abcd}}$ & $0.85^{\mathrm{a}}$ & $1.05^{\mathrm{ab} \backslash}$ & $1.21^{\mathrm{bcd}}$ & $1.07^{\mathrm{ab}}$ & $1.18^{\mathrm{bc}}$ & $1.26^{\mathrm{cd}}$ & $1.35^{\mathrm{d}}$ \\
\hline & 0.0005 & 0.12 & 0.12 & 0.09 & 0.09 & 0.08 & 0.08 & 0.08 & 0.08 \\
\hline \multirow[t]{2}{*}{$\mathrm{Sh}(\mathrm{Ba})$} & $0.0018 * * *$ & $0.85^{\mathrm{a}}$ & $0.89^{\mathrm{ab}}$ & $1.18^{\mathrm{b}}$ & $1.46^{\mathrm{c}}$ & $1.12^{\mathrm{ab}}$ & $1.36^{\mathrm{c}}$ & $1.39^{\mathrm{c}}$ & $1.36^{\mathrm{c}}$ \\
\hline & 0.0005 & 0.14 & 0.14 & 0.11 & 0.11 & 0.10 & 0.10 & 0.10 & 0.10 \\
\hline \multirow[t]{2}{*}{$\operatorname{Ev}(N)$} & $0.0005^{*}$ & $0.89^{\mathrm{c}}$ & $0.52^{\mathrm{a}}$ & $0.60^{\mathrm{a}}$ & $0.66^{\mathrm{ab}}$ & $0.62^{\mathrm{a}}$ & $0.68^{\mathrm{b}}$ & $0.69^{\mathrm{b}}$ & $0.74^{\mathrm{b}}$ \\
\hline & 0.0002 & 0.05 & 0.05 & 0.02 & 0.02 & 0.02 & 0.02 & 0.02 & 0.02 \\
\hline \multirow[t]{2}{*}{$\mathrm{Ev}(\mathrm{Ba})$} & $0.0009 * * *$ & $0.67^{\mathrm{abc}}$ & $0.55^{\mathrm{a}}$ & $0.67^{\mathrm{ab}}$ & $0.79^{\mathrm{c}}$ & $0.64^{\mathrm{a}}$ & $0.78^{\mathrm{c}}$ & $0.75^{\mathrm{bc}}$ & $0.75^{\mathrm{bc}}$ \\
\hline & 0.0002 & 0.05 & 0.05 & 0.03 & 0.03 & 0.03 & 0.03 & 0.03 & 0.03 \\
\hline \multirow[t]{2}{*}{$\mathrm{B}-\mathrm{P}(N)$} & $-0.0008^{* *}$ & $0.42^{\mathrm{ab}}$ & $0.73^{\mathrm{d}}$ & $0.64^{\mathrm{cd}}$ & $0.55^{\mathrm{abc}}$ & $0.61^{\mathrm{cd}}$ & $0.52^{\mathrm{b}}$ & $0.50^{\mathrm{ab}}$ & $0.46^{\mathrm{a}}$ \\
\hline & 0.0003 & 0.06 & 0.06 & 0.04 & 0.04 & 0.03 & 0.03 & 0.03 & 0.03 \\
\hline \multirow[t]{2}{*}{$\mathrm{B}-\mathrm{P}(\mathrm{Ba})$} & $-0.0007 * *$ & $0.63^{\mathrm{c}}$ & $0.60^{\mathrm{c}}$ & $0.53^{\mathrm{bc}}$ & $0.42^{\mathrm{a}}$ & $0.58^{\mathrm{c}}$ & $0.42^{\mathrm{a}}$ & $0.45^{\mathrm{ab}}$ & $0.44^{\mathrm{ab}}$ \\
\hline & 0.0003 & 0.06 & 0.06 & 0.05 & 0.05 & 0.04 & 0.04 & 0.04 & 0.04 \\
\hline \multirow[t]{2}{*}{$\operatorname{Sh}($ Size $)$} & -0.0002 & 1.30 & 1.48 & 1.31 & 1.29 & 1.28 & 1.37 & 1.30 & 1.31 \\
\hline & 0.0005 & 0.10 & 0.10 & 0.06 & 0.06 & 0.05 & 0.04 & 0.04 & 0.05 \\
\hline \multirow[t]{2}{*}{ Ev(Size) } & $-0.0005^{*}$ & 0.76 & 0.74 & 0.70 & 0.63 & 0.67 & 0.66 & 0.67 & 0.69 \\
\hline & 0.0002 & 0.05 & 0.05 & 0.03 & 0.03 & 0.02 & 0.02 & 0.02 & 0.02 \\
\hline \multirow[t]{2}{*}{ Incr. $\left(\mathrm{m}^{2} \mathrm{ha}^{-1}\right.$ year $\left.^{-1}\right)$} & $0.0014 * * *$ & $0.31^{\mathrm{a}}$ & $0.42^{\mathrm{abc}}$ & $0.46^{\mathrm{abc}}$ & $0.49^{\mathrm{bc}}$ & $0.53^{\mathrm{c}}$ & $0.50^{\mathrm{bc}}$ & $0.51^{\mathrm{c}}$ & $0.45^{\mathrm{ab}}$ \\
\hline & 0.0004 & 0.05 & 0.05 & 0.03 & 0.03 & 0.02 & 0.02 & 0.02 & 0.02 \\
\hline \multirow[t]{2}{*}{ Out. $\left(\mathrm{m}^{2} \mathrm{ha}^{-1}\right.$ year $\left.^{-1}\right)$} & $0.0061 * *$ & $0.22^{\mathrm{a}}$ & $0.65^{\mathrm{ab}}$ & $0.81^{\mathrm{b}}$ & $0.67^{\mathrm{ab}}$ & $0.63^{\mathrm{ab}}$ & $0.53^{\mathrm{ab}}$ & $0.53^{\mathrm{ab}}$ & $0.56^{\mathrm{ab}}$ \\
\hline & 0.0023 & 0.18 & 0.18 & 0.09 & 0.09 & 0.06 & 0.05 & 0.05 & 0.06 \\
\hline
\end{tabular}

For abbreviations of parameter names, see Section 2.3. Significance levels: $* p<0.05 ; * * p<0.01 ; * * *<0.001$. Different letters indicate significant differences in the post hoc Tukey test $(p<0.05)$ performed by means of the lsmeans R package and cld function. The respective standard errors are given in italics below the parameter estimates. As a rule, interactions of year and community types were not statistically significant

negative, albeit not differing significantly from 0 (Fig. 2b; Table 4).

During the entire study period, the lowest figures for density were obtained for communities occupying extreme positions on the main environmental gradient (Vaccinio uliginosiPinetum, Peucedano-Pinetum and Circaeo-Alnetum). Nevertheless, in statistical terms, the differences at community level were not significant (Table 4). The mean values for basal area were comparable for most community types, with the exception of Vaccinio uliginosi-Pinetum (Table 4).

\subsection{Increment and outgrowth}

In contrast to the two previous measures, the data for increment in basal area (Incr., $\mathrm{m}^{2} \mathrm{ha}^{-1}$ year ${ }^{-1}$ ) and for outgrowth (Out., $\mathrm{m}^{2} \mathrm{ha}^{-1}$ year $^{-1}$ ) showed upward trends over time (Table 3; Fig. 2c, d). In both cases, the results of the regression modelling suggested that the temporal trends for the two variables were valid statistically (Table 4). Just as with the two measures of stocking (density and stand basal area), increment and outgrowth (as measures of ecosystem productivity) were also most limited in the Vaccinio uliginosi-Pinetum community (Fig. 2c, d; Table 4).

\subsection{Species diversity}

The temporal trends for species diversity, as measured using four different Shannon indices, were generally positive (Table 3; Fig. 2e-h). Only in the case of Shannon index calculated for tree density $(\operatorname{Sh}(N))$ was it not possible to confirm statistically this overall trend (Fig. 2e; Table 4). The Shannon index calculated for basal area (Sh(BA)) seems to offer the best reflection of the differences between particular communities, with those occupying poor sites generally distinguished by their lower species diversity than communities occupying fertile soils (Fig. 2f; Table 4).

Overall trends for species dominance as represented by two B-P indices (for density and basal area) revealed declining dominance over time (Table 3; Fig. 2i, j). Both trends appeared to be statistically significant (Table 4). The values for 
the B-P(BA) index varied from ca. 0.4 for Tilio-Carpinetum typicum, Tilio-Carpinetum stachyetosum and CircaeoAlnetum to ca. 0.6 for Peucedano-Pinetum and Vaccinio uliginosi-Pinetum (Table 4). This result suggests that the communities occupying poor sites were associated with a higher probability that a single tree species will dominate community composition.

\subsection{Size differentiation}

The results obtained for the Shannon size diversity indices (Sh(Size) and Ev(Size)) suggest that all investigated community types were distinguished by a similar, rather high, level of variation in tree sizes (Fig. 2k, 1; Table 4). The Shannon size evenness index ( $\operatorname{Ev}(\operatorname{Size}))$ was somewhat more variable and tended to take on larger values for communities related to oligotrophic sites (i.e. Vaccinio uliginosi-Pinetum and Peucedano-Pinetum (Table 4). In line with the results of the statistical calculations, the downward trend with time noted for the latter index did achieve significance (Fig. 21; Table 4).

\subsection{Compositional trends}

The values assumed by similarity coefficients for tree species composition in 1936 and 2012 suggest strongly that most woodland communities occurring in Białowieża NP were compositionally unstable (Table 5, see also Fig. 3 ). In the case of almost all communities (other than Vaccinio uliginosiPinetum), the values of similarity coefficients calculated for tree densities $\left(S_{N}\right)$ during the first and most recent censuses are below 0.50. For three communities (Peucedano-Pinetum and two variants of Serratulo-Pinetum), these values amount to ca. 0.20 , indicating exceptionally high compositional instability.

First of all, pronounced changes occurred among the dominants, defined here as tree species distinguished by importance values greater than or equal to 15\% (Table 5). In 1936, in all communities but Vaccinio uliginosi-Pinetum, Norway spruce was the most important tree species. However, in 2012, the role of spruce had declined markedly, with the species losing dominant status in most cases. In several communities, spruce (in some cases, also birch) was replaced by hornbeam and, to some degree, also by lime. The only community type characterised by an increase in the importance of spruce over the study period was Vaccinio uliginosi-Pinetum (Table 5).

For minor tree species (importance values of less than $15 \%$ ), downward trends clearly prevailed. As a result, the current importance values for these species were lower in most community types than they were in 1936 (Table 6).

The changing roles of tree species in building Białowieża woodland communities are even better seen when considerations are limited to tree species composition of lower-stand strata containing trees of $5 \mathrm{~cm} \leq \mathrm{DBH}<20 \mathrm{~cm}$ (Table 7). In comparison with the 1936 situation, it is typical for lowerstand layers in most communities to contain a markedly smaller number of species today. Pine, aspen and maple are not represented at all, while the shares of other species like birch, oak and ash are much smaller than initially. Diminishing diversity of the lower-stand strata is also reflected by temporal change in the two Shannon diversity indices $(\operatorname{Sh}(N)$ and $\mathrm{Sh}(\mathrm{BA}))$, as calculated for small trees $(5 \mathrm{~cm} \leq \mathrm{DBH}<$ $20 \mathrm{~cm}$ ). The value of the first index declined from 1.036 in 1936 to 0.896 in 2012, while that of the second declined from 1.110 in 1936 to 0.980 in 2012.

\section{Discussion}

\subsection{Białowieża's natural woodland communities as a model for managed forest stands}

Numerous studies show that the long-term dynamics of Białowieża Forest have been influenced by a number of factors, including (1) past disturbances, both natural (storms,
Table 5 Coefficients measuring the similarity of tree species composition in 1936 and 2012 $\left(S_{N}=\right.$ similarity calculated for tree density; $S_{B A}=$ similarity calculated for basal area), as well as dominant tree species (importance value $\geq 15 \%$ ) in woodland communities occurring in Białowieża NP, for two record dates: 1936 (initial census) and 2012 (most recent census)

\begin{tabular}{llllll}
\hline Community type & \multicolumn{2}{l}{ Similarity } & & & Dominant tree species \\
\cline { 2 - 3 } \cline { 5 - 6 } & $S_{N}$ & $S_{B A}$ & & 1936 & 2012 \\
\hline$V u-P$ & 0.66 & 0.70 & & Birch, pine & Pine, spruce, birch \\
$P e-P$ & 0.24 & 0.77 & & Spruce, pine & Hornbeam, pine \\
$S-P m$ & 0.21 & 0.53 & & Spruce, birch, pine & Hornbeam, pine \\
$S-P t$ & 0.17 & 0.52 & & Spruce, oak & Hornbeam, oak, lime \\
$Q u-P$ & 0.44 & 0.72 & & Spruce, birch & Hornbeam, spruce \\
$T-C t$ & 0.49 & 0.82 & & Spruce, hornbeam & Hornbeam, lime \\
$T-C s$ & 0.49 & 0.83 & & Spruce, hornbeam & Hornbeam, lime \\
$C i-A$ & 0.48 & 0.78 & & Spruce, alder, ash & Alder, hornbeam, spruce \\
\hline
\end{tabular}

See Table 2 for abbreviations of community names 

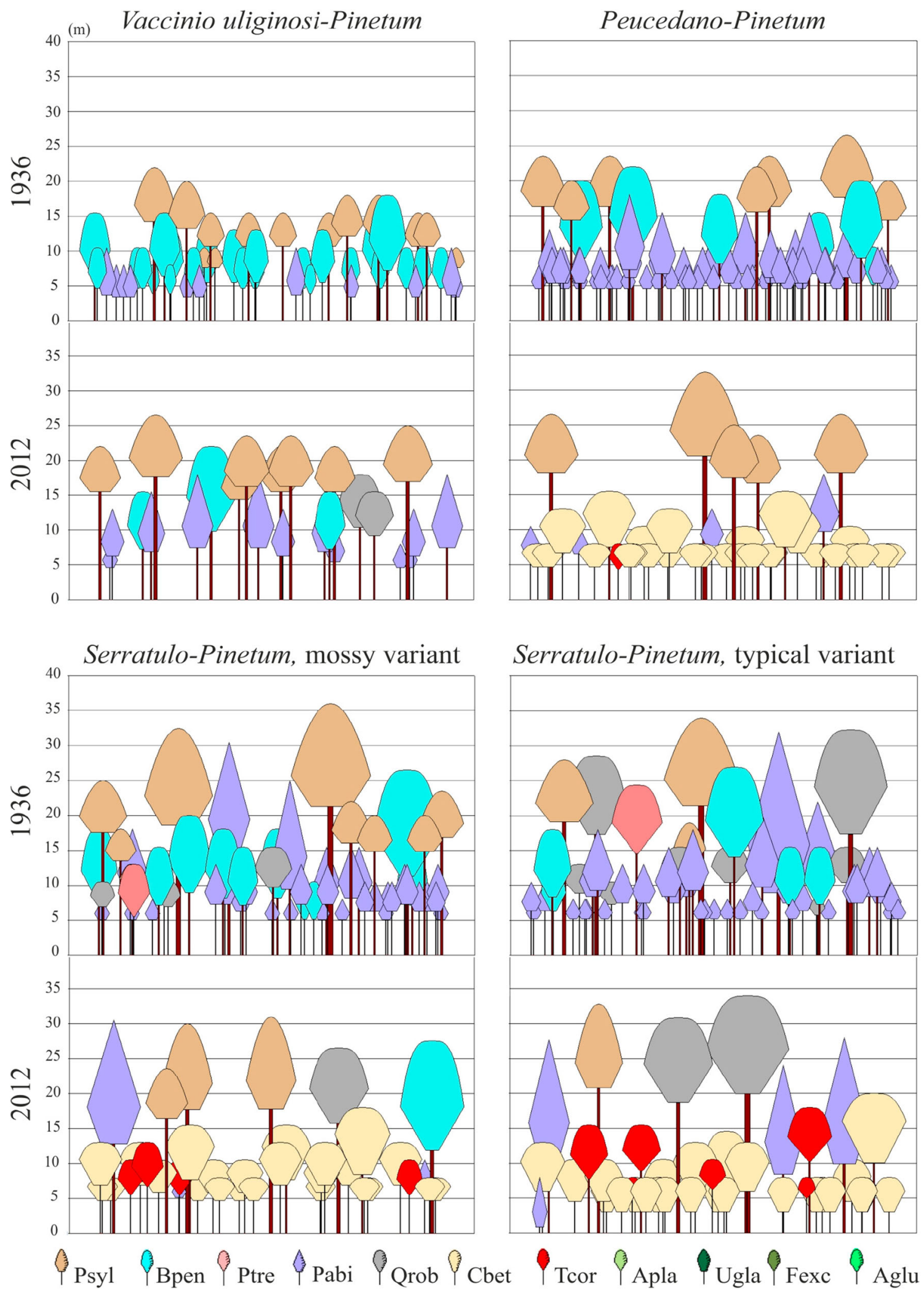

Serratulo-Pinetum, typical variant
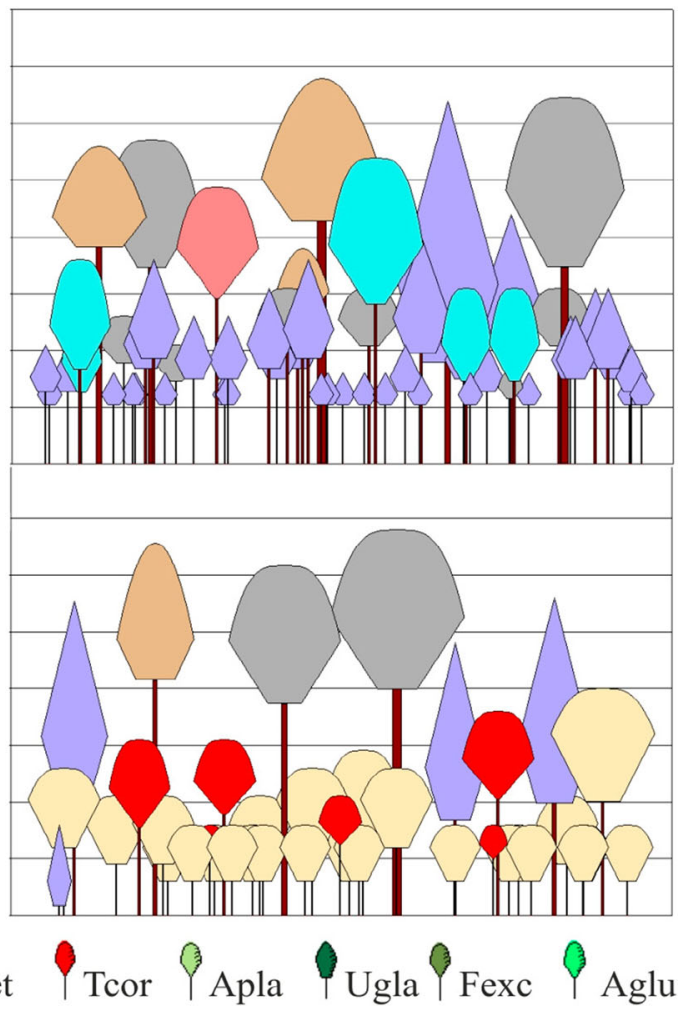

Fig. 3 Stand vertical profiles, depicting tree species composition and general stand structure of the Białowieża woodland communities, at the time of initial (1936) and most recent (2012) censuses. See Table 1 for abbreviations of tree species

insect-pest outbreaks, fires, changing wild game densities) and related to different human activities (such as hunting, cattle-breeding, beekeeping, selective logging, the baking of potash, distillation of tar and pitch), and (2) ongoing 

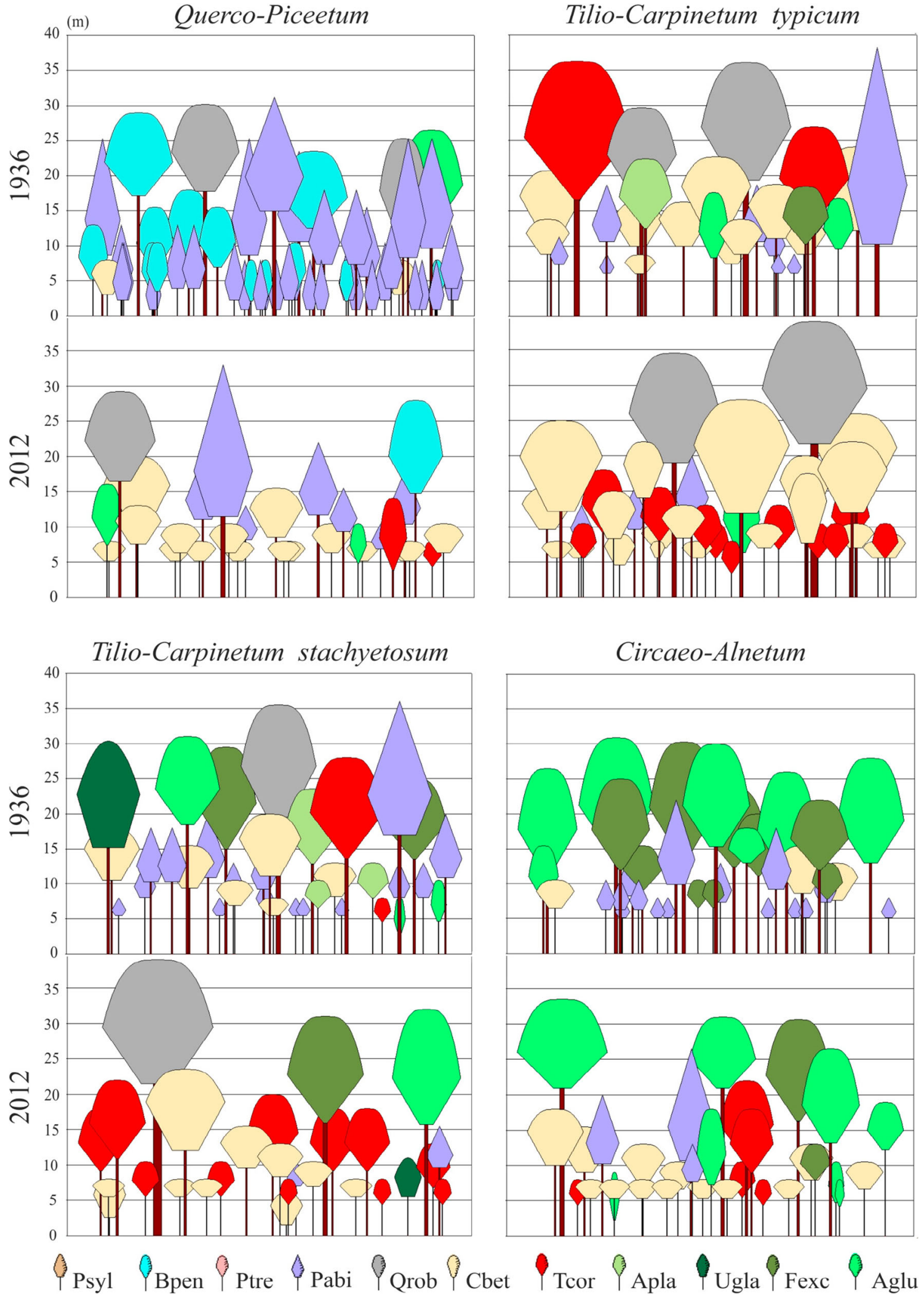

Fig. 3 (continued)

environmental changes $\left(\mathrm{CO}_{2}\right.$ increase, climate warming, nitrogen deposition, deer overabundance) (Paczoski 1930;
Matuszkiewicz 1952; Zaręba 1958; Faliński 1986, 1988; Kwiatkowska and Wyszomirski 1988; Jędrzejewska et al.

\section{QS Spriger}


Table 6 Importance values (\%) for tree species (calculated as an arithmetic average derived from both relative density and relative basal area), by community type, as determined for 1936 (first census, upper line) and 2012 (most recent census, lower line)

\begin{tabular}{|c|c|c|c|c|c|c|c|c|}
\hline Tree species & Vu-P & Pe-P & S-Pm & $\mathrm{S}-\mathrm{Pt}$ & $\mathrm{Qu}-\mathrm{P}$ & $\mathrm{T}-\mathrm{Ct}$ & T-Cs & $\mathrm{Ci}-\mathrm{A}$ \\
\hline Psyl & 37 & 34 & 20 & 10 & 3 & 1 & & \\
\hline Psyl & 45 & 36 & 19 & 6 & 1 & 0 & & \\
\hline Bpen & 53 & 9 & 21 & 14 & 16 & 2 & 0 & 0 \\
\hline Bpen & 21 & 3 & 4 & 6 & 3 & 0 & 0 & 0 \\
\hline Ptre & & 1 & 2 & 5 & 2 & 0 & 0 & \\
\hline Ptre & & & & 1 & 2 & 0 & 0 & \\
\hline$P a b i$ & 10 & 55 & 52 & 51 & 59 & 43 & 38 & 40 \\
\hline Pabi & 30 & 14 & 11 & 8 & 33 & 14 & 13 & 16 \\
\hline Qrob & & 1 & 5 & 18 & 10 & 11 & 6 & 5 \\
\hline Qrob & 4 & 1 & 7 & 22 & 14 & 9 & 8 & 6 \\
\hline Cbet & & & 0 & 0 & 4 & 27 & 27 & 7 \\
\hline Cbet & & 39 & 50 & 41 & 33 & 40 & 35 & 25 \\
\hline Tcor & & & & 1 & 1 & 10 & 8 & 1 \\
\hline Tcor & & 7 & 9 & 16 & 6 & 30 & 31 & 12 \\
\hline Apla & & & & & 2 & 4 & 6 & 1 \\
\hline Apla & & 0 & & 0 & 2 & 4 & 3 & 0 \\
\hline Ugla & & & & & 0 & 1 & 2 & 0 \\
\hline Ugla & & & 0 & 0 & 1 & 0 & 1 & 1 \\
\hline Fexc & & & & & 1 & 0 & 8 & 23 \\
\hline Fexc & & & & & 1 & 2 & 6 & 10 \\
\hline Aglu & & & & 1 & 3 & 1 & 5 & 24 \\
\hline Aglu & & & & 0 & 3 & 1 & 3 & 29 \\
\hline
\end{tabular}

See Tables 1 and 2 for abbreviations of species and community names. Absolute values of species density and basal area, by community type, are given in ESM Table 1 and ESM Table 2

1994; Kowalski 1994; Kwiatkowska 1994; Bernadzki et al. 1998; Mitchell and Cole 1998; Bobiec et al. 2000; Bobiec 2002, 2012; Sokołowski 2004; Keczyński 2007; Brzeziecki and Bernadzki 2008; Kuijper et al. 2010a, b; Niklasson et al. 2010; Samojlik 2010; Matuszkiewicz 2011; Brzeziecki et al. 2012, 2016, 2017; Mikusińska et al. 2013; Samojlik et al. 2013; Paluch 2015).

Still, many researchers conducting studies in Białowieża $\mathrm{NP}$, and, particularly in its core inner part enjoying protection as the strict reserve, have underlined the good state of preservation and model character of the woodland communities present (Faliński 1986, 1988; Bobiec et al. 2000; Bobiec 2002; Parviainen 2005; Wesołowski 2007; Mikusińska et al. 2013). On this basis, it has often been postulated that the most important features of the natural forest stands occurring in the area should be imitated in managed forests. In particular, the importance of reproducing, in managed forests, key attributes of primary and old-growth forests (such as dead/dying standing trees and downed coarse woody debris, as well as the occurrence of large and very large trees) has been pointed to
Table 7 Share (\%, based on stem number) of trees with $5 \mathrm{~cm} \leq \mathrm{DBH}<$ $20 \mathrm{~cm}$, by community type, as determined for 1936 (first census, upper line) and 2012 (most recent census, lower line)

\begin{tabular}{|c|c|c|c|c|c|c|c|c|}
\hline Tree species & Vu-P & Pe-P & S-Pm & S-Pt & Qu-P & $\mathrm{T}-\mathrm{Ct}$ & $\mathrm{T}-\mathrm{Cs}$ & $\mathrm{Ci}-\mathrm{A}$ \\
\hline Psyl & 16 & 1 & 2 & 1 & & 0 & & \\
\hline \multicolumn{9}{|l|}{ Psyl } \\
\hline Bpen & 61 & 1 & 13 & 7 & 22 & 2 & 1 & 0 \\
\hline Bpen & 23 & & & 0 & 2 & 0 & 0 & \\
\hline Ptre & & 0 & 1 & 2 & 1 & 0 & 1 & \\
\hline \multicolumn{9}{|l|}{ Ptre } \\
\hline Pabi & 23 & 97 & 78 & 77 & 64 & 67 & 65 & 63 \\
\hline Pabi & 74 & 8 & 10 & 6 & 14 & 4 & 4 & 5 \\
\hline Qrob & & 1 & 6 & 12 & 2 & 3 & 1 & 1 \\
\hline Qrob & 3 & & 0 & & & & & \\
\hline Cbet & & & 0 & 1 & 6 & 14 & 17 & 9 \\
\hline Cbet & & 80 & 81 & 77 & 74 & 62 & 49 & 47 \\
\hline Tcor & & & & & 0 & 12 & 3 & 0 \\
\hline Tcor & & 12 & 9 & 17 & 7 & 33 & 43 & 23 \\
\hline Apla & & & & & 2 & 1 & 2 & 1 \\
\hline Apla & & 0 & & 0 & & 0 & 0 & \\
\hline Ugla & & & & & 0 & 0 & 0 & \\
\hline Ugla & & & & & 1 & 0 & 2 & 1 \\
\hline Fexc & & & & & 0 & 0 & 1 & 10 \\
\hline Fexc & & & & & 0 & 0 & 1 & 2 \\
\hline Aglu & & & & 0 & 2 & 2 & 9 & 17 \\
\hline Aglu & & & & & 3 & 0 & 1 & 21 \\
\hline
\end{tabular}

See Tables 1 and 2 for abbreviations of species and community names, respectively. Absolute values for species density of trees with $5 \mathrm{~cm} \leq$ $\mathrm{DBH}<20 \mathrm{~cm}$, by community type, are given in ESM Table 3

frequently. An analysis of the long-term development of natural woodland communities occurring in Białowieża Forest (in the part protected strictly for about 100 years now) reveals that their living component also possesses several traits and attributes which are certainly worth seeking to achieve in managed forests.

Among other things, the communities investigated are characterised by relatively high levels of two measures of general stocking: tree density and stand basal area (on average, ca. 700 trees ha ${ }^{-1}$ for density and $35 \mathrm{~m}^{2} \mathrm{ha}^{-1}$ for basal area (for trees of $\mathrm{DBH} \geq 5 \mathrm{~cm}$ )). For comparison, the analogous values obtained by O'Hara et al. (2007) for tree stands managed with the plenter system (a management approach often described as close-to-nature) varied between ca. 300 and 800 trees ha $^{-1}$ (tree density) and between ca. 30 and $45 \mathrm{~m}^{2}$ (basal area).

Two measures of ecosystem productivity (increment and outgrowth) also showed rather high values in the analysed woodland communities (on average, ca. $0.49 \mathrm{~m}^{2} \mathrm{ha}^{-1}$ year and ca. $0.58 \mathrm{~m}^{2} \mathrm{ha}^{-1}$ year $^{-1}$, respectively). Both values lie within the ranges reported by O'Hara et al. (2007) for 
plenter-like stands, i.e. ca. $0.3-1.0 \mathrm{~m}^{2} \mathrm{ha}^{-1}$ year $^{-1}$ for increment and $0.0-1.5 \mathrm{~m}^{2} \mathrm{ha}^{-1}$ year $^{-1}$ for outgrowth.

The investigated woodland communities are also distinguished by high tree species richness. In all but the Vaccinio uliginosi-Pinetum communities, the total number of tree species present is in the 6-10 range, even if importance values for most of the species are relatively low (usually below 15\%), with just two to three conspicuous dominant species present as a rule.

Another feature of the natural woodland communities worth pointing out is their marked tree size variation, as represented by Shannon size diversity and Shannon size evenness. The long-term averages for the two parameters, displaying a high degree of temporal constancy, amounted to 1.47 and 0.69 , respectively. Similar values $(0.9-1.4$ for Shannon size diversity and 0.6-0.9 for Shannon size evenness) were obtained for stands managed under the plenter system (O'Hara et al. 2007).

Considering the relatively high temporal stability noted for most of the structural indices discussed above, averaged values can potentially play a role as reference figures for managed forest stands growing in similar site conditions. In other words, they can serve as measures helping to determine the extent to which different silvicultural activities and programmes imitate the structures and processes typical for natural forest (at least as far as live trees are concerned).

\subsection{Trends towards less diverse species composition of lower strata}

Notwithstanding the above findings, there remains a second group of parameters analysed in this paper, involving (1) the similarity coefficients used to measure constancy of tree species composition, (2) the importance values for tree species and (3) the tree species composition of lower-stand strata, suggesting that reference to natural woodland communities as a model for managed forests is a more complicated issue than it initially appears to be.

Specifically, the aforementioned indicators are alike in showing that distinct, qualitative changes in the composition of particular Białowieża woodland communities have occurred over the past $70-80$ years.

The changing roles of tree species in the composition of Białowieża woodland communities are, thus by far, the best seen in the lower-stand strata (comprising trees with DBH values between 5 and $20 \mathrm{~cm}$ ). These are currently characterised by the prevalence of just a very limited number of tree species (mainly hornbeam and lime) (Fig. 3). This dominance is accompanied by marked downward trends for many other tree species. Until now, these changes have not been detected by the structural indices analysed before (calculated for whole stands). Indeed, it is possible that the tendencies towards homogenisation observable in the lower-stand layers have, thus far, been masked by the diversity of upperstand layers, which is still relatively high (Fig. 3). This result confirms indirectly the importance of extreme longevity as a key feature of life-history strategies of trees. Thank to long lifespans of trees, upper-stand strata, containing large and old trees, can remain relatively stable over long time periods. However, it seems very probable that, in the course of time, the process of homogenisation will also come to involve the upper-stand layers, as a simple consequence of ongoing demographic processes (cf. also Brzeziecki et al. 2016, 2017).

Definitely, there is an important question as to the extent to which results in the present study (based on five plots with a total size amounting to ca. $15 \mathrm{ha}$ ) are representative for larger spatial scales (cf. e.g. Jaroszewicz et al. 2017). However, as we showed in our other paper (Brzeziecki et al. 2017), there is a good correlation between the data from permanent plots and the results of the recent large-scale forest inventory involving the whole territory of the Strict Reserve of Białowieża NP (i.e. an area of ca. $4700 \mathrm{ha}$ ). This fact suggests that, in the case of natural, strictly protected forest stands, homogenisation trends can indeed involve large temporal and spatial scales, covering several tens of years and several thousands of hectares (cf. also Schall et al. 2018).

\subsection{Creating compositionally diverse forest communities: a role for human intervention}

The tendencies described above (above all the compositional impoverishment of lower-stand strata) can hardly be judged worthy of imitation in managed stands, and this above all from the point of view of nature conservation. It is well known that every tree species (represented by both living and dead individuals) supports the occurrence and existence of different groups of other forest organisms (insects, fungi, birds, lichens, etc.) (Alexander et al. 2006). Thus, a declining diversity of tree species usually entails a more general loss of biodiversity (Franklin et al. 2002; Ellison et al. 2005; Barbier et al. 2009). This means that, in the case of managed forests, the use of appropriate silvicultural measures to maintain more diverse species mixtures and more balanced demographic structures (as a basic prerequisite if high levels of forest biodiversity are to be retained) would be very much indicated, even if this would occasionally mean a necessity of working "against natural processes" (Wohlgemuth et al. 2002). Apparently, ecological processes which operate in the case of natural forests take much larger spatial and temporal scales than are covered by typical, usually stand-based, silvicultural planning. In other words, while in the case of natural forest one can even wait hundreds of years until some tree species return or again increase in importance (in a given location), such a strategy, i.e. the long wait, can hardly be advocated for managed forests.

In this place, it is worth pointing out that, for Białowieża Forest, an active intervention and modification of natural 
structures and processes (obviously outside areas under strict protection) has been suggested by several researchers studying the area (i.e. Paczoski 1930; Matuszkiewicz 1952; Kwiatkowska and Wyszomirski 1990; Sokołowski 2004; Matuszkiewicz 2011). For example, in his outstanding, comprehensive botanical monograph devoted to Białowieża Forest, Paczoski (1930) suggested the promotion, by means of active silvicultural measures, of oak in the Carpinetum community (today's Tilio-Carpinetum), at the expense of hornbeam. Similar suggestions with regard to several different tree species (Scots pine, Norway maple, ash, elm and alder) have also been made by other researchers. They all postulated creating, by means of some active measures, a more balanced, more stable and more diverse tree species composition of forest stands, as a main prerequisite for maintaining their high natural values.

As a matter of fact, forest managers have several useful tools at their disposal, like selection of tree species, different types of regeneration cutting, application of artificial regeneration (planting), weed control, protection of trees vulnerable to browsing, and thinning of tree species capable of outcompeting all others. When wise and sensible use is made of all of these measures, they can help neutralise the adverse effects of different factors influencing the long-term development of natural forest stands (Kwiatkowska and Wyszomirski 1988; Kowalski 1994; Sokołowski 2004; Kuijper et al. 2010a, b; Matuszkiewicz 2011; Brzeziecki et al. 2012, 2013, 2016, 2017; Drozdowski et al. 2012; Paluch 2015). Above all, such measures can be used to counteract strong tendencies towards compositional homogenisation, as well as trends towards structural simplification that are also shown to characterise some types of natural forest (cf. Schütz 1999b, 2002; Schall et al. 2018).

\section{Conclusions}

There are several structural features of natural, strictly protected forest stands (like a mixed character, a wide range of tree sizes or a presence of so-called old-growth attributes) which are certainly worth emulating in contemporary forest management.

However, an analysis of the long-term (ca. 80-year) development of the life component of natural forest stands present in Białowieża NP reveals trends that hardly deserve to be followed under conditions of managed stands. The essence of these trends is the declining occurrence and reduced roles characteristic for a large number of tree species, leading to compositional simplification of tree stands.

Even if, in the case of strictly protected areas, such developments can be regarded as the manifestation of processes leading towards a tree species composition more in line with the potential natural vegetation, it is doubtful that the impact of this on modern-day silviculture should be for trends of this kind to be mimicked. As pointed out on different occasions by several authors, the major challenge and major responsibility of today's forestry are the creation of structurally and compositionally diverse, relatively stable forest stands that are able to adjust to ongoing changes in environmental conditions and capable of meeting steadily growing societal needs, expectations and requirements (Peterken 1999; Schütz 1999b, 2002; Spiecker 2003; Brang et al. 2014; O’Hara 2016; Schütz et al. 2016; Nolet et al. 2017). The example of Białowieża Forest makes it very clear that this goal is not likely to be achieved by mere imitation of natural processes.

Acknowledgments The authors thank James R.A. Richards for improving the English text, as well as three anonymous reviewers for their valuable comments and suggestions.

Funding This research was supported by the National Science Centre in Poland through resources provided by grant number N N309 701540.

Data availability The datasets generated and/or analysed during the current study are available in the dryad repository (Brzeziecki et al. 2018). Datasets are not peer reviewed.

\section{Compliance with ethical standards}

The authors obtained permission from the Director of Białowieża National Park to publish this research conducted in the protected area of Białowieża Forest (NE Poland).

Conflict of interest The authors declare that they have no conflicts of interest.

Open Access This article is distributed under the terms of the Creative Commons Attribution 4.0 International License (http:// creativecommons.org/licenses/by/4.0/), which permits unrestricted use, distribution, and reproduction in any medium, provided you give appropriate credit to the original author(s) and the source, provide a link to the Creative Commons license, and indicate if changes were made.

\section{References}

Alexander A, Butler J, Green T (2006) The value of different tree and shrub species to wildlife. Br Wildl 18:18-28

Badeck F-W, Lischke H, Bugmann H, Hickler T, Hönninger K, Lasch P, Lexer MJ, Mouillot F, Schaber J, Smith B (2001) Tree species composition in European pristine forests: comparison of stand data to model predictions. Clim Chang 51:307-347

Barbier S, Chevalier R, Loussot P, Bergès L, Gosselin F (2009) Improving biodiversity indicators of sustainable forest management: tree genus abundance rather than tree genus richness and dominance for understory vegetation in French lowland oak hornbeam forests. For Ecol Manag 258:176-186

Bauhus J, Puettmann K, Messier C (2009) Silviculture for old-growth attributes. For Ecol Manag 258:525-537 
Bernadzki E, Bolibok L, Brzeziecki B, Zajączkowski J, Żybura H (1998) Compositional dynamics of natural forests in the Białowieża National Park, North-Eastern Poland. J Veg Sci 9:229-238

Bobiec A (2002) Living stands and dead wood in the Białowieża Forest: suggestions for restoration management. For Ecol Manag 165:121136

Bobiec A (2012) Białowieża Primeval Forest as a remnant of culturally modified ancient forest. Eur J Forest Res 131:1269-1285. https:// doi.org/10.1007/s10342-012-0597-6

Bobiec A, van der BH, Meijer K, Zuyderduyn C, Haga J, Vlaanderen B (2000) Rich deciduous forests in Białowieża as a dynamic mosaic of developmental phases: premises for nature conservation and restoration management. For Ecol Manag 130:159-175

Bolibok L, Brzeziecki B (2000) Analiza wybranych zależności allometrycznych dla głównych gatunków drzew Białowieskiego Parku Narodowego. Sylwan 6:73-81

Brang P (2005) Virgin forests as a knowledge source for Central European silviculture: reality or myth? For Snow Landsc Res 79: $19-32$

Brang P, Spathelf P, Bo Larsen J, Bauhus J, Bončina A, Chauvin C, Drössler L, Garcia-Güemes C, Heiri C, Kerr G, Lexer MJ, Mason B, Mohren F, Mühlethaler U, Nocentini S, Svoboda M (2014) Suitability of close-to-nature silviculture for adapting temperate European forests to climate change. Forestry 87:492-503. https:// doi.org/10.1093/forestry/cpu018

Brzeziecki B, Bernadzki E (2008) Langfristige Entwicklung von zwei Waldgesellschaften im Białowieża-Urwald. Schweiz Z Forstwes 159:80-90

Brzeziecki B, Keczyński A, Zajączkowski J, Drozdowski S, Gawron L, Buraczyk W, Bielak K, Szeligowski H, Dzwonkowski M (2012) Zagrożone gatunki drzew Białowieskiego Parku Narodowego ("Rezerwat Ścisły"). Sylwan 4:252-261

Brzeziecki B, Drozdowski S, Bielak K, Buraczyk W, Gawron L (2013) Kształtowanie zróżnicowanej struktury drzewostanów w warunkach nizinnych. Sylwan 8:597-606

Brzeziecki B, Pommerening A, Miścicki S, Drozdowski S, Żybura H (2016) A common lack of demographic equilibrium among tree species in Białowieża National Park (NE Poland): evidence from long-term plots. J Veg Sci 27:460-467

Brzeziecki B, Drozdowski S, Żybura H, Bolibok L, Bielak K, Zajączkowski J (2017) Managing for naturalness alone is not an effective way to preserve all the valuable natural features of the Białowieża Forest - a reply to Jaroszewicz et al. J Veg Sci 28: 223-231. https://doi.org/10.1111/jvs. 12504

Brzeziecki B, Bielak K, Bolibok L, Drozdowski S, Zajączkowski J, Żybura H (2018) Data from: structural and compositional dynamics of strictly protected woodland communities with silvicultural implications, using Białowieża Forest as an example. Dryad Digital Repository [Dataset]. https://doi.org/10.5061/dryad.35vr46g

Burrascano S, Keeton WS, Sabatini FM, Blasi C (2013) Commonality and variability in the structural attributes of moist temperate oldgrowth forests: a global review. For Ecol Manag 291:458-479

Çolak AH, Rotherham ID, Çalikoglu M (2003) Combining "naturalness concepts" with close-to-nature silviculture. Forstw Cbl 122:421-431

Drozdowski S, Brzeziecki B, Żybura H, Żybura B, Gawron L, Buraczyk W, Zajączkowski J, Bolibok L, Szeligowski H, Bielak K, Widawska Z (2012) Wieloletnia dynamika starodrzewów w zagospodarowanej części Puszczy Białowieskiej: gatunki ekspansywne i ustępujące. Sylwan 156:663-671

Ellison AM, Bank MS, Clinton BD, Colburn EA, Elliott K, Ford CR, Foster DR, Kloeppel BD, Knoepp JD et al (2005) Loss of foundation species: consequences for the structure and dynamics of forested ecosystems. Front Ecol Environ 3:479-486

Faliński JB (1986) Vegetation dynamics in temperate lowland primeval forests. Ecological studies in Białowieża Forest. In: Geobotany, vol 8. Dr W. Junk Publishers, Dordrecht, pp 1-537
Faliński JB (1988) Succession, regeneration and fluctuation in the Białowieża Forest (NE Poland). Vegetatio 77:115-128

Faraway JJ (2016) Extending the linear model with R. generalized linear, mixed effects and nonparametric regression models. CRC Press, Taylor \& Francis Group, Boca Raton

Franklin JF, Spies T, Van Pelt R, Carey AB, Thornburgh DA, Rae Berg D, Lindenmayer DB, Harmon ME, Keeton WS, Shaw DC, Bible K, Chen J (2002) Disturbances and structural development of natural forest ecosystems with silvicultural implications, using Douglas-fir forests as an example. For Ecol Manag 155:399-423

Gamborg CH, Larsen JB (2003) 'Back to nature'-a sustainable future for forestry? For Ecol Manag 179:559-571

Jaroszewicz B, Bobiec A, Eycott AM (2017) Lack of demographic equilibrium indicates natural, large-scale forest dynamics, not a problematic forest conservation policy - a reply to Brzeziecki et al. J Veg Sci 28:218-222. https://doi.org/10.1111/jvs. 12458

Jędrzejewska B, Okarma H, Jędrzejewski W, Miłkowski L (1994) Effects of exploitation and protection on forest structure, ungulate density and wolf predation in Białowieża Primeval Forest, Poland. J Appl Ecol 31:664-676

Jones EW (1945) The structure and reproduction of the virgin forests of the north temperate zone. New Phytol 44:130-148

Keczyński A (2007) Regeneracja grądu Tilio-Carpinetum Tracz. 1962 w następstwie dawnego użytkowania lasu w Białowieskim Parku Narodowym. Sylwan 1:58-65

Kowalski M (1994) Zmiany składu gatunkowego lasów na tle zmian klimatu w ostatnich dwóch stuleciach. Sylwan 9:33-43

Kuijper DPJ, Cromsigt JPGM, Jędrzejewska B, Miścicki S, Churski M, Jędrzejewski W, Kweczlich I (2010a) Bottom-up versus top-down control of tree regeneration in the Białowieża Primeval Forest, Poland. J Ecol 98:888-899

Kuijper DPJ, Jędrzejewska B, Brzeziecki B, Churski M, Jędrzejewski W, Żybura H (2010b) Fluctuating ungulate density shapes tree recruitment in natural stands of the Białowieża Primeval Forest, Poland. J Veg Sci 1:1-17

Kwiatkowska AJ (1994) Changes in the species richness, spatial pattern and species frequency associated with the decline of oak forest. Vegetatio 112:171-180

Kwiatkowska AJ, Wyszomirski T (1988) Decline of Potentillo albaeQuercetum phytocoenoses associated with the invasion of Carpinus betulus. Vegetatio 75:49-55

Kwiatkowska AJ, Wyszomirski T (1990) Species deletion in Potentillo albae-Quercetum phytocoenoses reversed by the removal of Carpinus betulus. Vegetatio 87:115-126

Kwiatkowski W (1994) Vegetation landscapes of Białowieża Forest. Phytocoenosis. Phytocoenosis 6:35-87

Lähde E, Laiho O, Norokorpi Y (1999) Diversity-oriented silviculture in the boreal zone of Europe. For Ecol Manag 118:223-243

Leibundgut H (1959) Über Zweck und Methodik der Struktur- und Zuwachsanalyse von Urwälder. Schweiz Z Forstw 3:111-124

Leibundgut H (1982) Europäische Urwälder der Bergstufe. Haupt, Bern

Lenth RV (2016) Least-squares means: the R package lsmeans. J Stat Softw 69:1-33. https://doi.org/10.18637/jss.v069.i01

Matuszkiewicz W (1952) Zespoły leśne Białowieskiego Parku Narodowego. Ann UMCS Lublin Suppl 6:1-218

Matuszkiewicz JM (2002) Zespoły leśne Polski. PWN, Warszawa

Matuszkiewicz JM (2011) Changes in the forest associations of Poland's Białowieża Primeval Forest in the second half of the 20th century. Czas Geogr 82:69-105

Meyer P (2005) Network of strict forest reserves as reference system for close to nature forestry in Lower Saxony, Germany. For Snow Landsc Res 79:33-44

Mikusińska A, Zawadzka B, Samojlik T, Jędrzejewska B, Mikusiński G (2013) Quantifying landscape change during the last two centuries in Białowieża Primeval Forest. Appl Veg Sci 16:217-226 
Mitchell FJG, Cole E (1998) Reconstruction of long-term successional dynamics of temperate woodland in Bialowieża Forest, Poland. J Ecol 86:1042-1059

Nagel J, Schmidt M (2006) The silvicultural decision support system BWINPro. In: Hasenauer H (ed) Sustainable forest management. Growth models for Europe. Springer, Berlin, pp 59-63

Niklasson M, Zin E, Zielonka T, Feijen M, Korczyk A, Churski M, Samojlik T, Jędrzejewska B, Gutowski JM, Brzeziecki B (2010) A 350-year tree-ring fire record from Białowieża Primeval Forest, Poland: implications for Central European lowland fire history. J Ecol 98:1319-1329. https://doi.org/10.1111/j.1365-2745.2010. 01710.x

Nolet P, Kneeshaw D, Messier C, Béland M (2017) Comparing the effects of even- and uneven-aged silviculture on ecological diversity and processes: a review. Ecol Evol 8:1217-1226. https://doi.org/10. 1002/ece3.3737

O'Hara KL (2014) Multiaged silviculture: managing for complex forest stand structures. Oxford University Press, Oxford

O'Hara KL (2016) What is close-to-nature silviculture in a changing world? Forestry 89:1-6

O'Hara KL, Hasenauer H, Kindermann G (2007) Sustainability in multiaged stands: an analysis of long-term plenter systems. Forestry 80: $163-181$

Paczoski J (1930) Lasy Białowieży. PROP, Poznań

Paillet Y, Pernot C, Boulanger V, Debaive N, Fur M, Gilg O, Gosselin F (2015) Quantifying the recovery of old-growth attributes in forest reserves: a first reference for France. For Ecol Manag 346:51-64. https://doi.org/10.1016/j.foreco.2015.02.037

Paluch R (2015) Wieloletnie zmiany składu gatunkowego drzewostanów naturalnych w Puszczy Białowieskiej. Sylwan 4:278-288

Parviainen J (2005) Virgin and natural forests in the temperate zone of Europe. For Snow Landsc Res 79:9-18

Peterken GF (1996) Natural woodland: ecology and conservation in northern temperate regions. Cambridge University Press, Cambridge

Peterken GF (1999) Applying natural forestry concepts in an intensively managed landscape. Glob Ecol Biogeogr 8:321-328

Pinheiro J, Bates D, DebRoy S, Sarkar D, and the R Development Core Team (2013) Nlme: linear and nonlinear mixed effects models. R package version 3

Pommerening A, Murphy ST (2004) A review of the history, definitions and methods of continuous cover forestry with special attention to afforestation and restocking. Forestry 77:27-44

R Core Team (2018) R: a language and environment for statistical computing. R Foundation for Statistical Computing, Vienna, Austria. URL: http://www.R-project.org

Samojlik T (2010) Traditional utilisation of Białowieża Primeval Forest (Poland) in the 15th to 18th centuries. Landsc Archaeol Ecol 8:150 164
Samojlik T, Rotherham I, Jędrzejewska B (2013) Quantifying historic human impacts on forest environments: a case study in Białowieża Forest, Poland. Environ Hist 18:576-602. https://doi.org/10.1093/ envhis/emt039

Schall P, Gossner MM, Heinrichs S, Fischer M, Boch S, Prati D, Jung K, Baumgartner V, Blaser S, Böhm S, Buscot F, Daniel R, Goldmann K, Kaiser K, Kahl T, Lange M, Müller J, Overmann J, Renner SC, Schulze E-D, Sikorski J, Tschapka M, Türke M, Weisser WW, Wemheuer B, Wubet T, Ammer C (2018) The impact of evenaged and uneven-aged forest management on regional biodiversity of multiple taxa in European beech forests. J Appl Ecol 55:267-278. https://doi.org/10.1111/1365-2664.12950

Schütz J-P (1999a) Naturnaher Waldbau: gestern, heute, morgen Schweiz Z Forstw 150:478-483

Schütz J-P (1999b) Close-to-nature silviculture: is this concept compatible with species diversity? Forestry 72:359-366

Schütz J-P (2002) Silvicultural tools to develop irregular and diverse forest structures. Forestry 4:329-337

Schütz J-P, Saniga M, Diaci J, Vrška T (2016) Comparing close-to-nature silviculture with processes in pristine forests: lessons from Central Europe. Ann For Sci 73:911-921. https://doi.org/10.1007/s13595016-0579-9

Sokołowski A (2004) Lasy Puszczy Białowieskiej. CILP, Warszawa

Spiecker H (2003) Silvicultural management in maintaining biodiversity and resistance of forests in Europe-temperate zone. J Environ Manag 67:55-65

Stokland J, Siitonen J, Jonsson BG (2012) Biodiversity in dead wood. Cambridge University Press, Cambridge

Wesołowski T (2007) Primeval conditions - what can we learn from them? Ibis 149:64-77

Więcko E (1984) Puszcza Białowieska. PWN, Warszawa

Witkowska L (1956) Stosunki florystyczne w środowisku lasu liściastego na powierzchni badawczej w oddziale 370-371 Białowieskiego Parku Narodowego. Manuscript in the Department of Botany. Warsaw University of Life Sciences, Warsaw

Włoczewski T (1954) Materiały do poznania zależności między drzewostanem i glebą w przestrzeni i w czasie. Prace IBL 123: $161-249$

Wohlgemuth T, Bürgi M, Scheidegger C, Schütz M (2002) Dominance reduction of species through disturbance- - a proposed management principle for Central European forests. For Ecol Manag 166:1-15

Zaręba R (1958) Ślady działalności ludzkiej w drzewostanach Białowieskiego Parku Narodowego. Sylwan 8:9-18

Zaręba R (1972) Charakterystyka fitosocjologiczna powierzchni badawczej w oddziale 319 Białowieskiego Parku Narodowego. Fol For Polon Ser A 20:53-66

Zukrigl K (1991) Ergebnisse der Naturwaldforschung für den Waldbau. Schrreihe Vegkd 21:233-247 